\title{
How to Enhance Smart Work Effectiveness as a Sustainable HRM Practice in the Tourism Industry
}

\author{
Hyunjung (Helen) Choi ${ }^{1}{ }^{(}$, Jin Young Lee ${ }^{2}{ }^{(D}$, Youngjoon Choi ${ }^{3, *}$, Yuxian Juan ${ }^{4}$ and Choong-Ki Lee ${ }^{5, *(\mathbb{D}}$ \\ 1 Hotel Management Major, Tourism Management Division, Baekseok University, Chungcheongnam-do, \\ Cheonan-si 31065, Korea; chj043@bu.ac.kr \\ 2 Hotel \& Tourism Management Department, Woo Song University, Daejeon 34606, Korea; jylee1015@wsu.ac.kr \\ 3 Department of International Office Administration, College of Science \& Industry Convergence, \\ Ewha Womans University, Seoul 03760, Korea \\ 4 School of Tourism Management, Sun Yat-Sen University, Guangzhou 519000, China; juanyx@mail.sysu.edu.cn \\ 5 College of Hotel \& Tourism Management, Kyung Hee University, Seoul 02447, Korea \\ * Correspondence: young.choi@ewha.ac.kr (Y.C.); cklee@khu.ac.kr (C.-K.L.); \\ Tel.: +82-2-3277-5025 (Y.C.); +82-2-961-9430 (C.-K.L.)
}

check for updates

Citation: Choi, H.; Lee, J.Y.; Choi, Y.; Juan, Y.; Lee, C.-K. How to Enhance Smart Work Effectiveness as a Sustainable HRM Practice in the Tourism Industry. Sustainability 2022, 14, 2218. https://doi.org/10.3390/ su14042218

Academic Editor: Hak-Seon Kim

Received: 17 December 2021

Accepted: 7 February 2022

Published: 15 February 2022

Publisher's Note: MDPI stays neutral with regard to jurisdictional claims in published maps and institutional affiliations.

Copyright: (C) 2022 by the authors. Licensee MDPI, Basel, Switzerland. This article is an open access article distributed under the terms and conditions of the Creative Commons Attribution (CC BY) license (https:// creativecommons.org/licenses/by/ $4.0 /)$.

\begin{abstract}
With the development of information technologies and increasing interest in sustainability, many companies have adopted smart work as a sustainable human resource practice. Moreover, the outbreak of COVID-19 has further promoted smart work in the workplace. However, the benefits and disadvantages of smart work are still under debate. In this regard, this study attempted to delve into how to enhance smart work implementation by exploring employees' subjectivity. Hana Tour, which is considered a good model of smart work in South Korea, was selected as a sample company. Q-methodology was employed to listen to employees' subjective opinions about smart work that they experienced. This study identified five types of smart work perceptions, namely, "self-development and energy saving," "quality of personal life," “job satisfaction," “work engagement," and "worklife balance". Based on these five types, the theoretical and practical implications are discussed in the last chapter. Interestingly, the results showed that employees were not well aware of smart work effectiveness as one of the environmental protection practices in sustainability management paradigms. Another notable result was that employees were not concerned about the potential penalties of their engagement in smart work. During the current COVID-19 pandemic, the study's findings are beneficial to the improvement of smart work implementation as a sustainable HRM practice in business.
\end{abstract}

Keywords: smart work; subjectivity; sustainable HRM; Q-methodology; contactless work format

\section{Introduction}

Sustainable human resource management_- "Sustainable HRM"—is a sustainable personal system to achieve three core values of economic, social and environmental factors from "The 2030 agenda for sustainable development goals (SDGs)" announced by the UN General Assembly in 2015 [1,2]. Its main goal is to create employee value, such as enhancing employees' working conditions, employee capacity, health care, work-life balance, wellbeing, and justice in the workplace [3]. From this viewpoint, smart work can be considered one of the useful sustainable HR practices, since the basic idea of smart work is to actualize an ideal workplace to improve employees' well-being and overall quality of life $[4,5]$.

Smart work is an innovative work program that cares for employees through the use of telecommuting, flexible work locations and schedules among workers [6], and an employee-friendly work arrangement that can improve the workers' quality of life [7]. By using information communication technology (ICT), it enables employees to work via an online network system without restrictions in time and place. Even before the COVID-19 pandemic, there had already been time and resources invested to develop smart work 
systems for employees [8,9]. In particular, given that tourism and hospitality companies have put a lot of effort into making contactless working environments since the COVID-19 outbreak, more hotels and companies have been adopting smart work practices in the workplace [10].

In Korea, Hana Tour has been recognized as a good model ever since its introduction of smart work programs in 2011 [9]. Established in 1993, Hana Tour is the largest and most reputable travel company in South Korea with more than 4500 employees (including employees in subsidiaries), and 30 subsidiaries and branch offices around the world. Leading the growth of the Korean travel industry, Hana Tour has provided high-quality travel services and ranked first in terms of overseas travel and flight ticket sales over the past 20 years [11]. Hana Tour offers four types of smart work programs, namely, (1) home office, (2) smart work center, (3) flexible time (including discretion work), and (4) mobile work. Home office allows employees to work at home instead of commuting to the office. This smart work program is especially useful for working mothers who need time to take care of their children [12]. A smart work center allows employees to work at an office located closest to their homes, thereby saving them time, cost, and energy. Flexible time allows employees to choose when they work among five work-hour options (8 a.m.-5 p.m., 8:30 a.m.-5:30 p.m., 9 a.m.-6 p.m., 9:30 a.m.-6:30 p.m., and 10 a.m.-7 p.m.). As a type of flexible time arrangement, discretion work allows employees to perform any type of smart work when needed, but only once a week. Mobile work allows employees to perform their work anywhere outside the office.

Given the increasing usage and development of smart phones and portable devices, mobile work is becoming more common than any other type of smart work. The number of employees participating in smart work programs has increased every year, and 1223 employees (51.9\% of the total number of employees in the headquarter office) participated in smart work programs as of the end of July 2016 [5]. After implementing smart work in 2011, Hana Tour's corporate revenues increased by 59\% for four consecutive years, while its employee turnover rate decreased from 9.3\% in 2011 to 5.8\% in 2015 [9]. These figures are meaningful, because high turnover rate and low job satisfaction are critical issues related to work conditions in the tourism sector [13]. In addition, from the perspective of reducing time and energy in commuting, and putting effort into retaining employees, smart work shows fruitful outcomes in relation to the key spirit of sustainable management goals.

However, two conflicting viewpoints on smart work have been proposed. It seems positive that smart work brings many potential benefits not only for employees and organizations, but also for the environment and society $[6,14]$. On the other hand, smart work may generate negative results [15]. For instance, smart work ultimately cannot help employees separate their work from their personal lives. Moreover, employees engaging in smart work tend to feel isolated, due to their limited face-to-face interactions with their co-workers [16].

Based on these arguments on the potential benefits and drawbacks of smart work, this study attempted to discover more about how smart work affects employees' jobs and personal lives by collecting their subjective opinions. To this end, this study used Q-methodology to collect employees' detailed ideas about smart work that they have experienced. Hana Tour travel agency, which has been a good model of smart work in South Korea, was selected as a study sample company. Therefore, this study aims (1) to describe the employees' specific experiences of smart work in their work and personal lives, and (2) to identify the typology of employees' subjective opinions on smart work to show its effectiveness. By doing so, (3) the ultimate goal of this study is to delve into how to systemically improve current approaches to smart work implementation, not only as a sustainable human resource management tool (sustainable HRM), but also as a contactless work format.

Meanwhile, social exchange theory provides a grounded theoretical framework to understand the underlying reasons for smart work implementation [17]. Moreover, sus- 
tainable HRM [2] becomes a basis to discuss the managerial implications for facilitating smart work practices in business.

\section{Literature Review}

\subsection{Sustainable HRM and Social Exchange Theory}

As sustainability issues, such as environmental protection, people's well-being, and social accountability, have become more critical across the globe, people have become more interested in the sustainability of the business environment [18]. From this background, sustainable human resource management (sustainable HRM) was created as a novel personnel management concept [3]. Kramar (2014) defined sustainable HRM as a new approach to managing people by practicing a long-term human resource management strategy to achieve a company's financial, environmental, and social goals. It aims to create employee value, such as improvement of employees' working conditions and promotion of long-term employment capacity, employee health care, well-being, and justice within the workplace $[3,18]$. From this viewpoint, social exchange theory supports the importance of sustainable HRM.

Social exchange theory suggests that people interact with others according to the degree of benefits they receive [19]. Based on this theory, when a company shows its willingness to create a healthy and beneficial working environment for its employees, the employees feel obliged to reciprocate the benefits received. So, when employees perceive the workplace is beneficial, it is likely that their work performance can be improved and turnover rate may be reduced [20].

Meanwhile, smart work provides employees with the opportunity to choose their preferred times and locations for work. The increased flexibility and autonomy in smart work environments enhance employee's work-life balance and well-being [21] and also produce various positive job outcomes, such as job satisfaction and job performance [22]. According to social exchange theory, these positive outcomes from smart work increase employees' positive attitudes toward the organization [6,22].

\subsection{Concept of Smart Work}

Creating a smart environment in the workplace plays a key role in improving working conditions, innovation, sustainability, competitiveness, and quality of life [4]. Since computers and digital networks were brought into the workplace in the late 1970s, "telework" has become a buzz word among researchers and businesspeople [23]. Meanwhile, the increasing usage of smartphones and broadband connections has promoted various forms of telework across several industries [24]. The development of ICT has also created a highly virtualized, flexible, and mobile-friendly work context, and removed the past restrictions that limited employees to working in specific places [23].

Telework is a work arrangement that allows employees to perform ordinary work within scheduled working and paid hours at an approved alternative worksite, such as their homes and telework centers. Telework also allows people to work while walking on the street [6]. This concept is similar to virtual work, telecommuting, remote work, and flexible work, all of which have been successfully practiced in many European countries and in the US for many years [24].

Although smart work is similar to telework, these two concepts show differences in their scope of activities, places, and devices. For example, telework primarily aims to reduce commuting time and costs for employees by allowing them to work at a remote place located away from the headquarter office. By contrast, smart work allows employees to work at any time and in any place by using their mobile devices to access the information systems of their organizations [8]. Many employees have started to work outside their offices by using virtual communication tools, such as mobile intranet with a remote log-in, video conference, and teleconference. This study follows the definition of Eom et al. ([8], p. 562), who described smart work as "a work system by using telecommunications, mobile devices, 
and computer-based technologies that allows employees to undertake their labor activities at any permitted time and place".

In line with the worldwide proliferation of innovative work arrangements, the Korean government launched the "Smart Work Initiative" in 2010 to progressively reinforce the implementation of smart work throughout the country, starting from public sector employees.

\subsection{Effectiveness of Smart Work}

Previous studies have identified the potential benefits and drawbacks of smart work for the performance of employees and organizations. The common benefits of smart work for employees are saving commuting time and cost, spending more time with families, improving quality of life, maintaining work-life balance, and increasing the flexibility and autonomy in the workplace [25]. Enhancing task performance, job satisfaction [26], work morale [27], corporate image [28] work engagement [29], and organizational performance by reducing absenteeism and turnover intention are further positive outcomes of smart work [13]. Increasing work productivity by minimizing interferences during work hours, such as a noisy and disruptive office environment, was mentioned as an advantage of smart work [30]. It can also contribute to the environment by reducing air pollution and saving time and energy generated by commuting [14]. Moreover, in the time of COVID-19, smart work has become a necessity, not an option, in the workplace [31].

However, many negative effects of smart work have also been reported. For instance, smart work may disrupt the development of teamwork and collaboration because team members are not co-located in the same space [32]. Smart work may hinder the building of trust and the frequent exchange of information among team members [15]. Moreover, smart work employees experience isolation and lack of work involvement because they are given limited opportunities to interact with their co-workers [25]. Some researchers argue that the negative effects of smart work can reduce employees' job satisfaction, identification with their organizations, and organizational commitment [33]. Interestingly, even if most companies implement smart work to enhance the work-life balance of their employees, some studies show that such initiative may even induce work-family conflicts by constantly interrupting employees with email and calls from their co-workers. Likewise, smart work may blur the boundaries between the work and personal life of employees [34].

\section{Methodology}

Q-methodology uses a two-step sampling procedure: the first step collects subjective data extracting from samples (called Q-population), along with materials, such as newspaper articles, government reports, and TV news, and the second step requires samples (called P-samples) to sort the Q-sample statement.

\subsection{Q-Population and Sample Selection}

To secure the Q-population, the perceptions of Hana Tour employees toward smart work were collected from various materials, such as newspaper articles, government reports, and TV news. Moreover, from 8 to 12 January 2018, we interviewed ten Hana Tour employees who engaged in smart work. A total of 66 items were initially extracted. After deleting those items that were duplicated or did not meet the research purpose, 38 items were eventually included in the Q-sample (Table 1).

\subsection{P-Sample}

$\mathrm{Q}$ is a small-sample methodology, and the size needs to be decided for the purpose and topic of the study. To represent the opinions of employees engaging in smart work, 25 employees were included in the P-sample based on their demographic characteristics, job position, type of smart work programs, and duration of smart work experience. The 25 employees who participated in the study were different from the ten employees interviewed to collect the Q-population. 
Table 1. Q-sample statements and standard scores.

\begin{tabular}{|c|c|c|c|c|c|c|}
\hline & \multirow[b]{2}{*}{ Statement } & \multicolumn{5}{|c|}{ Standard Score (Z-Score) } \\
\hline & & $\begin{array}{c}\text { Type } \\
\text { I }\end{array}$ & $\begin{array}{l}\text { Type } \\
\text { II }\end{array}$ & $\begin{array}{l}\text { Type } \\
\text { III }\end{array}$ & $\begin{array}{l}\text { Type } \\
\text { IV }\end{array}$ & $\begin{array}{c}\text { Type } \\
\text { V }\end{array}$ \\
\hline 1 & My job satisfaction is improved. & 0.98 & 1.01 & $2.05 *$ & 0.07 & 0.74 \\
\hline 2 & My turnover intention has decreased. & 0.76 & 0.50 & -0.06 & -1.09 & -0.60 \\
\hline 3 & My attachment to the company has grown. & 0.52 & 0.51 & $1.69 *$ & -0.36 & -0.52 \\
\hline 4 & It is convenient because I pay less attention on my clothing. & 0.57 & -0.46 & 0.04 & 0.58 & 1.07 \\
\hline 5 & $\begin{array}{l}\text { I do not need to read my colleagues' countenance when I leave the } \\
\text { office at the usual time. }\end{array}$ & 0.29 & -0.03 & 0.10 & -0.86 & -0.89 \\
\hline 6 & $\begin{array}{l}\text { I do not need to read my boss' countenance when I leave the office at } \\
\text { the usual time. }\end{array}$ & 0.56 & -0.14 & 0.10 & 0.07 & -0.14 \\
\hline 7 & My work stress is reduced. & -0.03 & -0.55 & 0.80 & -0.36 & -0.23 \\
\hline 8 & My work engagement is improved. & -0.16 & 1.21 & $1.57 *$ & $2.02 *$ & 1.18 \\
\hline 9 & Smart work can enhance my creativity. & -1.05 & -0.31 & 1.03 & $-2.02 *$ & -0.96 \\
\hline 10 & Smart work makes me feel more responsible to my work. & -0.13 & 0.39 & 0.79 & 0.00 & 0.47 \\
\hline 11 & I can immerse myself further in my work. & -0.04 & 0.80 & $1.50 *$ & 1.01 & 1.02 \\
\hline 12 & Smart work can contribute to an increase in birth rates. & -0.27 & -0.92 & -1.17 & -1.09 & -1.24 \\
\hline 13 & $\begin{array}{l}\text { I can contribute to environmental protection by using less energy or } \\
\text { reducing carbon emissions. }\end{array}$ & -0.47 & -0.78 & 0.10 & $-2.02 *$ & -1.59 * \\
\hline 14 & Smart work is beneficial for parenting and housekeeping. & 1.04 & $1.73 *$ & -1.28 & 0.43 & $2.10 *$ \\
\hline 15 & The balance between my work and life is improved. & $1.53 *$ & $1.67 *$ & $1.93 *$ & 0.65 & -1.06 \\
\hline 16 & My time with my family has increased. & 0.98 & 1.43 & -0.05 & -0.13 & $1.81 *$ \\
\hline 17 & The boundary between my work and personal life is blurred. & -1.04 & -1.20 & -0.67 & -0.86 & 0.90 \\
\hline 18 & $\begin{array}{l}\text { I can develop myself by attending private educational institutes or } \\
\text { doing exercises. }\end{array}$ & 1.91 * & 1.46 & 1.21 & $1.95 *$ & 0.70 \\
\hline 19 & My commuting expenses are reduced. & 1.21 & 0.02 & -0.48 & -1.29 & -0.77 \\
\hline 20 & I can reduce personal maintenance costs. & 1.04 & -0.14 & 0.10 & -0.36 & -0.81 \\
\hline 21 & The reduction in commuting time is beneficial. & $1.87 *$ & $1.52 *$ & 0.96 & 0.65 & 1.77 * \\
\hline 22 & Smart work improves my quality of life. & 1.01 & 1.94 * & 0.90 & 1.01 & 0.10 \\
\hline 23 & $\begin{array}{l}\text { I can avoid the rush hour by using public transportation or avoid a } \\
\text { traffic jam. }\end{array}$ & 1.79 * & 0.91 & 0.11 & 1.44 & $1.92 *$ \\
\hline 24 & It is difficult to manage and control employees. & -0.89 & $-1.75 *$ & -0.58 & 1.29 & -0.22 \\
\hline 25 & The company's inside information can be easily leaked. & -1.00 & -1.46 & -1.25 & -0.58 & -0.33 \\
\hline 26 & The synergy effect of co-working is decreased. & -1.01 & -0.09 & -0.54 & -0.07 & 0.52 \\
\hline 27 & Sharing work-related information is difficult. & -0.77 & -1.38 & -0.51 & -0.15 & -0.32 \\
\hline 28 & $\begin{array}{l}\text { It feels inconvenient due to the increased reporting and documentation } \\
\text { works for meetings. }\end{array}$ & $-1.51 *$ & -0.58 & -0.64 & -0.07 & -0.85 \\
\hline 29 & I cannot easily communicate with the other employees. & -0.82 & -1.16 & -1.21 & 0.79 & 0.77 \\
\hline 30 & I feel lonely because I am separated from my colleagues. & -0.45 & -0.19 & -1.13 & 0.79 & -0.58 \\
\hline 31 & I feel less attached to my colleagues. & -0.76 & -0.68 & -1.34 & 0.28 & -0.26 \\
\hline 32 & $\begin{array}{l}\text { There are less opportunities for me to engage in socializing activities, } \\
\text { such as congregate dinners. }\end{array}$ & -0.30 & -0.21 & 0.66 & -0.07 & 0.22 \\
\hline 33 & I do not feel any pleasure from working with my colleagues. & -0.50 & 0.29 & -1.01 & 0.36 & -0.91 \\
\hline 34 & I am reluctant to apply for an annual leave or vacation. & -1.45 & -1.00 & -0.89 & -1.29 & -1.21 \\
\hline 35 & It is inconvenient because my boss scolded me more often. & $-1.80 *$ & -0.98 & -0.51 & $-1.52 *$ & -0.66 \\
\hline 36 & My sense of belonging is lowered. & -0.40 & -0.73 & -0.16 & 1.29 & -0.10 \\
\hline 37 & $\begin{array}{l}\text { I worry about the possible disadvantages in staff performance } \\
\text { appraisal. }\end{array}$ & -0.67 & 0.29 & -0.95 & 0.07 & $-1.62 *$ \\
\hline 38 & I feel uncomfortable visiting the headquarter offices to attend meetings. & -0.51 & -0.90 & -1.20 & -0.58 & 0.59 \\
\hline
\end{tabular}

${ }^{*}$ Most representative Q-statements of each type.

\subsection{Q-sorting and Data Processing}

The respondents included in the P-sample were invited to the Q-sorting procedure from 5 to 12 February 2018. First, these respondents were asked to sort 38 Q-sample statements into 3 types (i.e., agreement, neutrality, and disagreement) based on their opinion. Second, the respondents were asked to arrange these Q-sample statements from right (most agreeable) to left (most disagreeable) on the Q-sort table according to their degree of agreement or disagreement. Third, the respondents were asked to confirm the 
arrangement of these statements on the Q-sort table. A follow-up interview was conducted with these respondents to explore their reasons for choosing the two most agreeable and two most disagreeable statements. After Q-sorting, the most agreeable, neutral, and most disagreeable items were assigned with 1,5 , and 9 points, respectively. The QUANL PC program was then used to analyze the data.

\section{Results}

\subsection{Respondents' Subjective Perspectives toward Smart Work}

A total of 25 Hana Tour employees who engaged in smart work were classified into 5 types based on their subjectivity. The number of types was determined based on eigenvalue (1.00 or greater). Eigenvalues of Types I to V were 12.36, 2.53, 1.63, 1.16, and 1.10 , respectively.

Table 2 presents the factor weight values of the P-sample. A higher factor weight corresponds to a better representation of the characteristics of a certain type [35]. Respondents 12, 7, 25,22 , and 13 were identified as the most representative Types I to $\mathrm{V}$ respondents, respectively.

Table 2. P-sample typology and factor weight value.

\begin{tabular}{|c|c|c|c|c|c|c|c|c|c|}
\hline Type & P-Sample & Gender & Age & $\begin{array}{l}\text { Marital } \\
\text { Status }\end{array}$ & $\begin{array}{l}\text { No. of } \\
\text { Children }\end{array}$ & Position & $\begin{array}{l}\text { Participated Smart } \\
\text { Work Program(s) }\end{array}$ & $\begin{array}{l}\text { Duration } \\
\text { (Months) }\end{array}$ & $\begin{array}{l}\text { Factor } \\
\text { Weight }\end{array}$ \\
\hline \multirow{10}{*}{ Type I } & 4 & $\mathrm{~F}$ & $20 \mathrm{~s}$ & Single & None & Staff & Smart work center/Mobile Work & 36 & 0.62 \\
\hline & 10 & $\mathrm{~F}$ & $40 \mathrm{~s}$ & Single & None & Junior manager & Smart work center & 10 & 0.65 \\
\hline & 11 & $\mathrm{~F}$ & $30 \mathrm{~s}$ & Single & None & Junior manager & $\begin{array}{l}\text { Home office/Flexible time/ } \\
\text { Smart work center }\end{array}$ & 12 & 0.54 \\
\hline & 12 & $\mathrm{~F}$ & $30 \mathrm{~s}$ & Married & None & Junior manager & Smart work center & 12 & 0.81 \\
\hline & 15 & $\mathrm{~F}$ & $30 \mathrm{~s}$ & Married & None & Junior manager & Home office & 24 & 0.75 \\
\hline & 16 & $\mathrm{~F}$ & $30 \mathrm{~s}$ & Married & None & Junior manager & Smart work center & 24 & 0.57 \\
\hline & 17 & $\mathrm{~F}$ & $20 \mathrm{~s}$ & Single & None & Staff & Flexible time/Smart work center & 12 & 0.72 \\
\hline & 18 & F & $30 \mathrm{~s}$ & Single & None & Junior manager & Flexible time/Smart work center & 18 & 0.55 \\
\hline & 20 & F & $40 \mathrm{~s}$ & Married & 1 & Junior manager & Home office/Flexible time & 60 & 0.69 \\
\hline & 23 & $\mathrm{~F}$ & $40 \mathrm{~s}$ & Married & 1 & Senior manager & Smart work center/Mobile work & 21 & 0.66 \\
\hline \multirow{6}{*}{ Type II } & 5 & M & $30 \mathrm{~s}$ & Married & 1 & Junior manager & Flexible time/Smart work center & 24 & 0.49 \\
\hline & 6 & M & $40 \mathrm{~s}$ & Single & 1 & Senior manager & Smart work center & 24 & 0.69 \\
\hline & 7 & F & $30 \mathrm{~s}$ & Married & 2 & Senior manager & Home office/Flexible time & 24 & 0.74 \\
\hline & 9 & $\mathrm{~F}$ & $30 \mathrm{~s}$ & Single & None & Junior manager & Smart work center & 36 & 0.61 \\
\hline & 14 & M & $40 \mathrm{~s}$ & Married & 1 & Senior manager & Smart work center & 12 & 0.71 \\
\hline & 19 & F & $30 \mathrm{~s}$ & Married & 2 & Senior manager & Home office & 36 & 0.67 \\
\hline \multirow{4}{*}{ Type III } & 1 & $\mathrm{~F}$ & $40 \mathrm{~s}$ & Single & None & Senior manager & Flexible time/Smart work center & 11 & 0.70 \\
\hline & 8 & $\mathrm{M}$ & $30 \mathrm{~s}$ & Single & None & Junior manager & Smart work center & 10 & 0.60 \\
\hline & 21 & $\mathrm{M}$ & $30 \mathrm{~s}$ & Married & None & Junior manager & Smart work center & 18 & 0.64 \\
\hline & 25 & F & $50 \mathrm{~s}$ & Single & None & Managing director & Discretion work & 12 & 0.85 \\
\hline \multirow{2}{*}{ Type IV } & 2 & F & $40 \mathrm{~s}$ & Married & None & Senior manager & Flexible time/Smart work center & 3 & 0.52 \\
\hline & 22 & F & $30 \mathrm{~s}$ & Single & None & Junior manager & Flexible time/Smart work center & 12 & 0.89 \\
\hline \multirow{3}{*}{ Type V } & 3 & $\mathrm{~F}$ & $30 \mathrm{~s}$ & Married & 1 & Junior manager & Smart work center & 36 & 0.57 \\
\hline & 13 & $\mathrm{~F}$ & $40 \mathrm{~s}$ & Married & None & Senior manager & Home office & 24 & 0.78 \\
\hline & 24 & F & $50 \mathrm{~s}$ & Married & 1 & Senior manager & Home office & 36 & 0.74 \\
\hline
\end{tabular}

The subjectivity of Hana Tour employees was assessed in five steps. First, the Types I to $\mathrm{V}$ respondents were named after the statements that received the highest standard score (z-score) for each type. The standard score of the Q-sample represented the overall opinion of each type. Positive and negative scores increased as more participants of each type agreed and disagreed with a statement, respectively. Second, the characteristics of each 
type were described by analyzing those statements with relatively high (1.5 or more) and low standard scores $(-1.5$ or less). Third, follow-up interviews were conducted with two participants from each type who obtained the highest factor weights to explain the unique characteristics of each type. These interviewees included respondents 12 and 15 from Type I, respondents 7 and 14 from Type II, respondents 25 and 1 from Type III, respondents 22 and 2 from Type IV, and respondents 13 and 24 from Type V.

\subsection{Types of Smart Work Perceptions}

\subsubsection{Type I: Self-Development and Energy Saving}

Type I was named "self-development and energy saving group" based on item 18 (see Table 3), which obtained the highest standard score (1.91). They perceived that smart work could help them achieve self-development, reduce their commuting time, and avoid rush hour. Reducing commuting time saved time for them to engage in self-development activities. These respondents demonstrated meaningful achievements in terms of selfdevelopment, because they were relatively young, and were working in junior positions. They disagreed most with items 35 and 28, thereby indicating that they tended to hold positive attitudes toward the effectiveness of smart work, and experienced minimal effects when engaging in such activity.

Table 3. Type I and representative Q-sample.

\begin{tabular}{cccc}
\hline No. & Q-Sample & Z-Score \\
\hline 18 & I can develop myself by attending private educational institutes or doing exercises. & 1.905 \\
21 & The reduction in commuting time is beneficial. & 1.865 \\
23 & I can avoid the rush hour by using public transportation or avoid a traffic jam. & 1.785 \\
15 & The balance between my work and life is improved. & 1.533 \\
28 & It feels inconvenient due to the increased reporting and documentation works for meetings. & -1.509 \\
35 & It is inconvenient because my boss scolded me more often. & -1.798 \\
\hline
\end{tabular}

The most representative P-sample was respondent 12 , who obtained the highest factor weight (0.81). Respondent 12 was a female junior manager in her 30s who worked in a smart work center for 12 months. She agreed most with items 18 and 19. For item 18, she claimed, "The most important benefit of smart work was saving time. I felt good because by engaging in smart work, I have enough time to do exercises or learn something new after work". She agreed with item 19 because "I saved a lot of commuting expenses because I live near the smart work center". She disagreed the most with items 32 and 35. She explained, "Since we are working apart, we have more chances to socialize and attend congregate dinners, and I feel that my team leader takes care of me more often" and "I didn't feel that my team leader scolds me more often".

The second most representative Type I respondent was respondent 15 (factor weight $=0.75$ ), a female junior manager who worked in a home office for 36 months. She agreed the most with items 21 and 23. She argued, "I used to spend one hour to go to work, but now I only spend $30 \mathrm{~min}$, which is almost half of my original commuting time. Even if I get up late and have to take a taxi, the fares are affordable during off-peak hours. I used my saved commuting time by attending an educational program in a private institute near my office". For item 23, she explained, "The smart work center is located opposite to the city center. I am glad that I can easily find a seat on the subway or public transportation because by engaging in smart work, I can go to work outside rush hour". Similarly to respondent 12 , she argued that smart work helped her save some time to engage in selfdevelopment activities.

\subsubsection{Type II: Quality of Personal Life}

Type II was named "quality of life group" based on its most representative statement (item 22) (see Table 4). The Type II respondents perceived that smart work effectively helps them improve their quality of personal life. Although they prioritize their family life above 
anything else, they used to have a low life satisfaction and spend a limited time with their families before they engaged in smart work. Given the time-saving benefits of smart work, they believed that working in a home office gave them more time to fulfill their parenting duties and do their housework, which eventually improved their work-life balance and quality of life. These respondents disagreed the most with item 24 , thereby indicating that smart work had no negative effects on company management and operation.

Table 4. Type II and representative Q-sample.

\begin{tabular}{ccc}
\hline No. & Q-Sample & Z-Score \\
\hline 22 & Smart work improves my quality of life. & 1.938 \\
14 & Smart work is beneficial for parenting and housekeeping. & 1.726 \\
15 & The balance between my work and life is improved. & 1.671 \\
21 & The reduction in commuting time is beneficial. & 1.522 \\
24 & It is difficult to manage and control employees. & -1.749 \\
\hline
\end{tabular}

Among the Type II respondents, respondent 7 (a female senior manager in 30s who was working flexible hours in a home office) obtained the highest factor weight (0.81). She agreed the most with items 8 and 15. In the follow-up interview, she explained her agreement with item 8: "When I work in the company office, I get a lot of miscellaneous work from my boss and sudden requests from the other staff. However, when I work in the home office, I only have few things to consider, thereby allowing me to fully concentrate on my work. Smart work also helped me improve my work efficiency and quality of life". For item 15, she said, "I could save a lot of time by not commuting to the office and attending company lunches or dinners. I used the saved time to take care of personal stuff, which helped me maintain my work-life balance". She disagreed the most with items 7 and 24: "Because I can easily check my assigned tasks through Hana Talk (Hana Tour's internal messenger application) and the company's communication system, I think that the company can still control its staff effectively. However, my work stress was not reduced because I still received continuous work requests when working at home".

The second most representative respondent in Type II was respondent 14, a male senior manager in his 40s who was working in a smart work center. He agreed the most with items 21 and 16. For item 21, he explained, "Working in a smart work center allowed me to save a substantial amount of commuting time, probably more than $40 \mathrm{~min}$. When I work in the office, I had to spend a lot of time meeting people. Engaging in smart work helped me save time from such activity as well". He agreed with item 16 because "I could spend the saved time with my family. My wife used to prepare the family dinner, but by working in a smart work center, I can help her prepare our food. I also have more time to take care of my children, so I am quite satisfied with my current life". He disagreed the most with items 13 and 17. For item 13, he stated, "I use public transportation, such as the bus or subway train, to go to work because driving my personal vehicle would only emit greenhouse gases. So I believe that engaging in smart work does not contribute at all to environment protection as I need to use transportation anyway". For item 17, he explained, "Given that I still have the same work requirements, and work system, I can clearly distinguish my work from my personal life".

\subsubsection{Type III: Job Satisfaction}

Type III was named "job satisfaction group". Type III respondents agreed the most with item 1, followed by items 15 and 3 (see Table 5). Before engaging in smart work, these respondents were dissatisfied with their jobs and experienced many challenges. Smart work helped them overcome such challenges, increase their work engagement, and improve their attitudes toward their company. Such changes eventually helped improve their work-life balance and job satisfaction. Although these respondents did not assign low standard scores $(-1.5$ or less) to any of the statements, they perceived that smart work both had positive and negative effects. 
Table 5. Type III and representative Q-sample.

\begin{tabular}{ccc}
\hline No. & Q-Sample & Z-Score \\
\hline 1 & My job satisfaction is improved. & 2.048 \\
15 & The balance between my work and life is improved. & 1.926 \\
3 & My attachment to the company has grown. & 1.686 \\
8 & My work engagement is improved. & 1.572 \\
11 & I can immerse myself further in my work. & 1.502 \\
\hline
\end{tabular}

The most representative P-sample was respondent 25, a female managing director (or higher) in her 50s who was engaging in discretion work. She agreed the most with items 1 and 15. For item 1, she explained, "Given that discretion work allows me to spend one to two days per month to attend to my personal needs or to see my doctor, I am satisfied with my job, thanks to my company". For item 15, she shared, "I think that the balance between my work and life was substantially improved because I could adjust my work schedule according to my personal needs". She disagreed the most with item 14: "Not just because I am single, but I think that two days of discretion work per month does not greatly contribute to my housework".

The second most representative respondent in Type III was respondent 1 , a female senior manager in her 40s who was working flexible hours in a smart work center. She agreed the most with items 1 and 3 . For item 1, she said, "Our company provides us with unique work programs unlike other travel companies. Therefore, I felt different from those people working in other travel companies. I believe that our company has excellent employee welfare. After the implementation of smart work programs, my job satisfaction was greatly improved". Similarly, for item 3, she mentioned, "I think that our company cares more about its employees compared with the other companies". She disagreed the most with items 25 and 24 and shared that "The employees understand how the company prioritizes the prevention of inside information leakage. I think that the company's internal investigations also enhance information security". For item 24, she said, "The company manages the work time, outside duties, work attitudes, and work performances of its staff, and our system can monitor our work time and work attitudes. When engaging in outside work duties, we are required to inform our colleagues in advance. Work performance is a KPI (key performance index), so I believe that our staff is well-managed and controlled in general".

\subsubsection{Type IV: Work Engagement}

Type IV was named "work engagement group". Based on their responses to items 8 and 18 (see Table 6), these respondents perceived work engagement as the greatest benefit of smart work programs. They were also able to spend more time in developing themselves, as can be seen in the improvements in their work engagement and efficiency. However, they disagreed the most with items 9 and 13. Unlike the Types I to III respondents, the Type IV respondents argued that despite the positive effects of smart work, this initiative has a limited effect on the social contributions and individual talents of employees.

Table 6. Type IV and representative Q-sample.

\begin{tabular}{ccc}
\hline No. & Q-Sample & Z-Score \\
\hline 8 & My work engagement is improved. & 2.023 \\
18 & I can develop myself by attending private educational institutes or doing exercises. & 1.948 \\
35 & It is inconvenient because my boss scolded me more often. & -1.517 \\
13 & I can contribute to environmental protection by using less energy or reducing carbon emissions. & -2.023 \\
9 & Smart work can enhance my creativity. & -2.023 \\
\hline
\end{tabular}

Among the Type IV respondents, respondent 22 (a female junior manager in her 30 s who was working flexible hours in a smart work center) was identified as the most 
representative. She agreed the most with item 8 and 18. She explained, "I felt that my work engagement has improved a lot. In fact, when working in our headquarter office, I do a lot of unnecessary work. For instance, I needed to take care of visitors, which is not part of my responsibilities. When my co-workers want to communicate face to face, I had to visit them and spend much time moving around". She added, "In the headquarter office, I sometimes cannot complete my work because I have to handle other miscellaneous tasks. There were a lot of times that I couldn't go home just to please my boss. By engaging in smart work, I could save commuting time and focus more on my work. My work efficiency was improved and I could go home on time because I don't need to consider the feelings of my boss. I could have more discretionary time to do exercises or go to private educational institutes". However, she disagreed with items 9 and 13. She shared, "Because I am doing the same tasks, smart work does not necessarily improve my creativity. Also, I didn't feel that smart work can contribute to environment protection".

Among the Type IV respondents, respondent 2 (a female senior manager in her $40 \mathrm{~s}$ who was working flexible hours in a smart work center) was identified as the second most representative. She agreed the most with items 8 and 16. For item 8 , she mentioned, "I could focus on my work without any interruptions, such as unexpected meetings and sudden checks. I could also entirely focus on some tasks that require my full attention for many hours without any external disturbances". For item 16, she explained that "Because the smart office is located close to my home, I could save a lot of commuting time and spend more time with my family. Also, smart commuting (different time-set work) allows me to eat breakfast with my family". She disagreed the most with items 9 and 13 because "I think that smart work is not related to creativity. Regardless of the location of my workplace, headquarter office, or smart office, I have to do the same tasks. Moreover, a different time-set work cannot improve my creativity. Although some may see improvements in their creativity depending on the nature of their work, I do not feel the same way". She added, "I do not perceive a close relation between smart work and environment. I do not even have my own vehicle".

\subsubsection{Type V: Work-Life Balance}

Type V was named "work-life balance group" based on item 14 . These respondents agreed the most with item 14, followed by items 23, 16, and 21 (see Table 7). They perceived that smart work helped them save commuting time and reduce their psychological and physical burdens by enabling them to avoid the rush hour. Therefore, they could spend more time with their families and help with parenting duties and housework. The Type $V$ respondents were all married and female. They did not think that smart work contributed to social responsibility the same way that it contributed to environment protection. They were not worried about the potential negative effects of not working with their boss in the same office, and they tended to trust their company's promotion and staff-evaluation system.

Table 7. Type V and representative Q-sample.

\begin{tabular}{ccc}
\hline No. & Q-Sample & Z-Score \\
\hline 14 & Smart work is beneficial for parenting and housekeeping. & 2.096 \\
23 & I can avoid the rush hour by using public transportation or avoid a traffic jam. & 1.919 \\
16 & My time with my family has increased. & 1.806 \\
21 & The reduction in commuting time is beneficial. & 1.766 \\
13 & I can contribute to environmental protection by using less energy or reducing carbon emissions. & -1.588 \\
37 & I worry about the possible disadvantages in staff performance appraisal. & -1.621 \\
\hline
\end{tabular}

Among the Type $\mathrm{V}$ respondents, respondent 13 (a female senior manager in her $40 \mathrm{~s}$ who was working in a home office) was identified as the most representative. She agreed the most with items 16 and 23. She said, "I used to move back and forth from my home to my headquarter office all the time. Through smart work, I could work in my house or my mother's house, thereby allowing me to spend more time with my family". She added, 
"I used to spend 1.5 to $2 \mathrm{~h}$ going to the headquarter office. Going through crowded places is very exhausting. The same can be said about going back home. Working in a home office reduced such burdens, and I felt relaxed when doing housework". For items 13 and 20, she explained, "Because I had to use the same amount of electricity, water, and energy at home, I didn't think that smart work is related to the environment" and "My personal maintenance cost has increased after participating in smart work. I had to spend more time preparing my meals at home, and my electricity and water bills have increased".

The second most representative Type $V$ respondent was respondent 24 , a female senior manager in her 50s who was working in a home office. She agreed the most with items 14 and 17 because "Most employees engaging in the home office program may choose to work in a home office instead of a smart center because they need to take care of their kid(s). For me, the best part of working in a home office is that my child feels most comfortable when I am personally taking care of him. Apart from driving him to school or private institutes, I could give him snacks during his breaks". For item 17, she shared, "Although my work hours are set up, a home office does not have a closing time because I should respond to the questions and requests of the other staff even after my work hours. This is the biggest disadvantage of working in a home office. Although I can take care of my child, I also have to continuously fulfill work requests. My son often eats his dinner while I am working". She disagreed the most with items 12 and 34 because "Since I have a child, it does not influence me" and "For my team, we can freely use our leave days to go on a vacation. When we apply for a leave, it is immediately approved".

Figure 1 illustrated five types of smart work based on the smart work perceptions mentioned above.

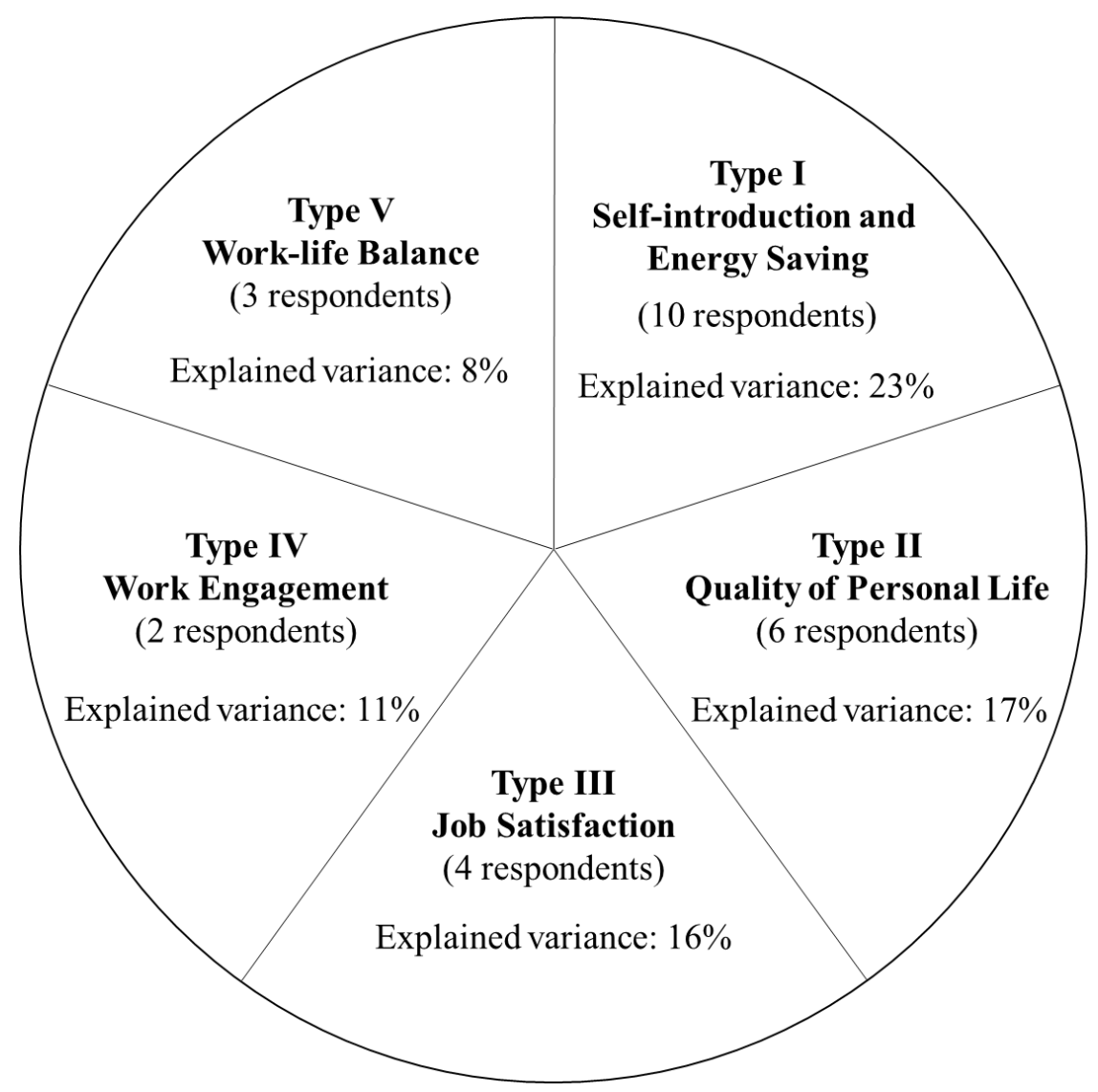

Figure 1. Typology of smart work participants' subjectivity. Note: Total variance explained by Types I to $\mathrm{V}=75 \%$. 


\section{Discussion}

Smart work is an employee-friendly work arrangement to improve workers' quality of life by providing telecommuting, flexible work locations and schedules among workers [6]. From the viewpoint of making more effort to increase employees' life value, the spirit of smart work aligns well with sustainable HRM practice.

This study aimed to delve into how to enhance smart work implementation by exploring employees' subjective opinions toward smart work programs they experienced. Based on the employees' subjective perspectives gained from Q-method, five types of smart work effectiveness were identified, namely, self-development and energy saving, quality of life, job satisfaction, work engagement, and work-life balance. This study was theoretically developed based on social exchange theory. Furthermore, this study's findings contributed to achieving sustainable development goals (SDGs) by establishing proper managerial implications for how to enhance smart work in future strategies for sustainable HRM practice.

\subsection{Theoretical Contribution}

According to the arguments in previous studies (e.g., [6]), opinions from various sources must be gathered to further understand the potential benefits and drawbacks of smart work. In order to meet the previous suggestions to understand smart work better, this study endeavored to employ Q-methodology to understand more about employees' perception to smart work program. The reason for applying Q-methodology to this study was because it elicits diverse and comprehensive responses to subjective domains by using broad sources of data. Therefore, Q-method helps the researcher to understand a certain topic in more detail $[36,37]$. Thus, unlike studies which solely rely on interview or survey data, this study used the ideas, opinions, and feelings of employees, obtained from diverse data sources, such as news articles, online communications, and in-depth interviews. A set of $38 \mathrm{Q}$-sample statements extracted in this study broadly reflects the uniqueness and subjectivity of employees who are working in different job positions, facing different family situations, and engaging in different types of smart work programs.

To the best of the authors' knowledge, applying Q-method to smart work paradigms was undertaken for the first time in this study. From this methodological attempt, this study theoretically contributes to the literature by providing more detailed and subjective information about smart work effectiveness.

Social exchange theory is a useful theoretical framework to interpret how employees perceive and appreciate the input of their employer to improving the quality of work environment. The efforts made by a company to create employee-perspective policies can lead to positive employee attitudes toward the organization, such as work engagement, and can encourage them to reciprocate the benefits they receive from the organization $[19,20]$. Meanwhile, several studies mentioned that smart work systems created work-life conflicts [34], reduced job satisfaction [33], and decreased work engagement [25]. However, the results of this study show clear positive outcomes from smart work implementation, such as enhancing job satisfaction, work engagement, self-development, work-life balance, and quality of life. Therefore, this study provided theoretical evidence of the social exchange theory that employers' efforts to support employees, such as smart work programs, leads to positive employee attitudes to their organization. Furthermore, the employees' subjective opinions toward smart work program obtained in this study indicate how we might obtain these kinds of positive performances from smart work systems.

\subsection{Practical Implications}

These findings provide useful suggestions for developing human resource strategies that can facilitate the successful adoption and implementation of smart work systems. As observed in the opinions of respondents 12 and 15 (Type I) and respondent 2 (Type V), by engaging in such programs, employees could save time and energy required for commuting and/or social gathering. As a result, the time and energy saving could also increase other 
personal benefits and social effectiveness. First, personally, employees used such time for self-development by attending private educational institutes or training workshops, enrolling in online academic courses, continuing their studies, developing their skills, and/or exercising. The saved time also helped them maintain their work-family balance by spending more time with their families. Interestingly, this is the opposite result to the previous study of [34], which argued that smart work reduced work-life balance, and increase work-family conflict [38]. However, this study apparently showed that smart work is beneficial to save employees' time, which is a key factor positively affecting their wellbeing, encouraging self-development and maintaining better work-life balance. Second, socially, the results suggest that smart work is a good way of practicing social and environmental sustainability management by saving commuting energy and supporting employees' self-development, as well as their personal wellbeing. Based on these results, this study recommends that companies continue providing their employees opportunities to utilize the time and energy they save through engaging in smart work.

The findings from Type III respondents also show that self-development opportunities through smart work can ultimately increase employees' job satisfaction. This is an inverse result to the previous study of Golden [33], which mentioned that smart work decreased job satisfaction. However, this study revealed that in a smart work system, employees feel that they receive unique welfare benefits that cannot be found in other companies, and this can be significantly linked to increasing job satisfaction. Furthermore, working with flexible hours and workplaces can positively affect many aspects of their lives, both in the workplace and at home. This study shows that providing these employees with various options to engage in smart work programs, such as smart work centers, home offices, mobile offices, flexible time, and discretion work, can bring them substantial benefits, and eventually also increase their job satisfaction.

In the meantime, sustainable HRM practice is defined as personnel activities with the purpose of achieving social, economic, and environmental goals. In HRM practice, social sustainability encourages companies to perform their social responsibilities by putting value on social issues, such as poverty, income inequality, health care, and education, not only in society but also for employees. Economic sustainability is a factor that must be met for financial success, and it should be beneficial for both outside and inside stakeholders. Environmental sustainability means that business must consider its impact on natural resources, the environment, and global warming [39]. This study shows that all five types of smart work effectiveness, which are self-development and energy saving (Type I), quality of life (Type II), job satisfaction (Type III), work engagement (Type IV), and work-life balance (Type V), are linked to sustainable HRM practice. More specifically, self-development (Type I), quality of life (Type II), and work-life balance (Type V), are related to the social dimension. Energy saving (Type I) is connected to the environmental factor. Finally, job satisfaction (Type III) and work engagement (Type V) are related to the economic area, as it is known that increasing employee job satisfaction and work engagement significantly affect company performance [25].

Additionally, according to Tremblay and Thomsin [25], employees involved in smart work tend to experience isolation and lack of work involvement due to limited opportunities to interact with their co-workers. However, according to respondent 12 in the Type II group in this study, it was revealed that home office work environments without any face-to-face interactions could rather help increase work concentration by reducing the occurrence of unnecessary meetings and miscellaneous work requests during work hours. In addition, in her follow-up interview, her answers let us know that through the efforts and support of the supervisor, employees can be prevented from feeling isolated from the organization. Similarly, the findings of this study also showed that this kind of non-face-to-face work positively affects the relationship between supervisor and employees, depending on the supervisor's attitude. Furthermore, in Korean culture, people believe that everything goes well in a happy household [9,40]. In line with this belief, the respondents perceived much improvement in their quality of life with enhancement of their 
work-life balance, because they had enough time to do their household work and fulfill their parenting duties. Especially during the COVID-19 pandemic, employees' preference for fewer face-to-face interactions in the workplace has increased [41]. As more people have experienced work from home during the pandemic, the need for smart work will remain high even after COVID-19 [42].

One noticeable drawback of smart work found in this study was that several respondents felt that smart work blurred the boundaries between their work and life. Therefore, in order to create highly effective smart work environments, "etiquettes in smart work practice" should be established to help employees maintain the boundaries between their work and life, both at the workplace and at home.

As shown by the answers of respondent 7 in Type II, some respondents perceived that working at a distance rather increased their attachment to the company. They felt that their team members more strongly cared for one another because they did not see one another very often. The interview results also showed that the major reason that the Hana Tour employees did not mention much about the disadvantages of engaging in smart work was the internal messenger and communication application system. In addition, in their work performance program named KPI, they seemed to trust their company's management and evaluation system, and were not concerned about the potential penalties of their engagement in smart work. These findings highlight the importance of establishing an accurate operation system for commuting checks, and a fair personnel evaluation system to facilitate an effective implementation of smart work and to increase employee satisfaction.

On the other hand, it is interesting to note that employees tend not to link the value of smart work programs to sustainability management practice. Literally, several respondents, such as 14 in Type II, 2 and 22 of Type IV, and 13 in Type V answered that they did not perceive a close relation between smart work and environmental protection. However, it is well known that environmental protection is one of the key benefits of smart work $[14,30]$. Therefore, companies need to let employees perceive that smart work is a very effective way to contribute to the social and environmental aspects of sustainability management. Promoting this kind of positive impact of smart work on sustainability management practice can be helpful for increasing the pride of employees who are currently engaged in smart work, and to invite environment-conscious employees to participate in such activities. Moreover, smart work contributes to enhancing a company's image compared to other firms that do not practice it. Furthermore, smart work is greatly useful as a contactless work system during the COVID-19 outbreak, since smart work offers many work options without any face-to-face interaction. From this point of view, this study hopes to provide useful sources to improve the effectiveness of the contactless working system, such as smart work.

\subsection{Limitations and Future Research}

This study has limitations, since it only focuses on one large-scale company. Future studies on small/medium-size companies in different types of businesses can enhance our understanding on smart work effectiveness. This study presented several aspects in results, including multiple outcomes of smart work, such as job satisfaction, work engagement, and work-life balance. A field survey with a large number of respondents may also be conducted to retest and compare the findings. The study findings would provide useful foundations to further delve into the effectiveness of smart work operation and arrangements for future studies.

Author Contributions: Writing manuscript, H.C.; idea and interviews, J.Y.L.; editing and implication, Y.C.; methodology, Y.J.; supervision and editing, C.-K.L. All authors have read and agreed to the published version of the manuscript.

Funding: This research received no external funding.

Institutional Review Board Statement: Institutional Review Board Statement is not required for this paper in South Korea. 
Informed Consent Statement: Informed consent was obtained from all subjects involved in the study.

Conflicts of Interest: The authors declare no conflict of interest.

\section{References}

1. Chams, N.; García-Blandón, J. On the importance of sustainable human resource management for the adoption of sustainable development goals. Int. J. Prod. Econ. 2019, 140, 219-226. [CrossRef]

2. Palm, K.; Bergman, A.; Rosengren, C. Toward more proactive sustainable human resource management practices? A study on stress due to the ICT-Mediated integration of work and private life. Sustainability 2020, 12, 8303. [CrossRef]

3. Wikhamn, W. Innovation, sustainable HRM and customer satisfaction. Int. J. Hosp. Manag. 2019, 76, 102-110. [CrossRef]

4. Scholl, H.J.; Scholl, M.C. Smart Governance: A Roadmap for Research and Practice. In iConference 2014 Proceedings; iSchools: Grandville, MI, USA, 2014; pp. 163-176.

5. Hana Tour. Expansion of Smart Work Center, 500 Project; Hana Tour Human Resource Management Report: Seoul, Korea, 9 August 2016.

6. Kwon, M.; Jeon, S.H. Why permit telework? Exploring the determinants of California city gevernments' decisions to permit telework. Public Pers. Manag. 2017, 46, 239-262. [CrossRef]

7. Nedelcu, E. The perspective of young people on the effects of telework on the quality of life at work. Rom. Rev. Soc. Sci. 2020, 11, 3-12.

8. Eom, S.J.; Choi, N.B.; Sung, W. The use of smart work in Korea: Who and for what? In Proceedings of the 15th Annual International Conference on Digital Government Research; Association for Computing Machinery: New York, NY, USA, 2014; Volume 18, pp. 253-262.

9. Kang, Y.Y. Good Day, I'll Work at Home! Midas News. Available online: http://www.yonhapmidas.com/article/160907204550_6 81501 (accessed on 1 November 2017).

10. Choi, M.; Choi, Y. Employee perceptions of hotel CSR activities during the COVID-19 pandemic. Int. J. Contemp. Hosp. Manag. 2021, 33, 3355-3378. [CrossRef]

11. Hana Tour. Hana Tour Homepage, Company Introduction. Available online: http://www.hanatourcompany.com/eng/compan y/intro.asp (accessed on 24 February 2018).

12. Troup, C.; Rose, J. Working from home: Do formal or informal telework arrangements provide better work-family outcomes? Community Work Fam. 2012, 15, 471-486. [CrossRef]

13. McNall, L.A.; Masuda, A.D.; Nicklin, J.M. Flexible work arrangements, job satisfaction, and turnover intentions: The mediating role of work-to-family enrichment. J. Psychol. 2009, 144, 61-71. [CrossRef]

14. Boell, S.K.; Cecez-Kecmanovic, D.; Campbell, J. Telework paradoxes and practices: The importance of the nature of work. New Technol. Work Employ. 2016, 31, 114-131. [CrossRef]

15. Caillier, J.G. Does satisfaction with family-friendly programs reduce turnover? A panel study conducted in U.S. federal agencies. Public Pers. Manag. 2016, 45, 284-307. [CrossRef]

16. Crandall, W.; Gao, L. An update on telecommuting: Review and prospects for emerging issues. Adv. Manag. J. 2005, 70, 30-37.

17. Pailleé, P.; Grima, F.; Dufour, M.-È. Contribution to social exchange in public organizations: Examinig how support, trust, satisfaction, commitment and work outcomes are related. Int. J. Hum. Resour. Manag. 2015, 26, 520-546. [CrossRef]

18. Kramar, R. Beyond strategic human resource management: Is sustainable human resource management the next approach? Int. J. Hum. Resour. Manag. 2014, 25, 1069-1089. [CrossRef]

19. Homan, G. Social behavior as exchange. Am. J. Soc. 1958, 63, 597-606. [CrossRef]

20. Cropanzano, R.; Mitchell, M. Social exchange theory: An interdisciplinary review. J. Manag. 2005, 31, 874-899. [CrossRef]

21. Langè, V.; Gastaldi, L. Coping Italian Emergency COVID-19 through Smart Working: From Necessity to Opportunity. J. Mediterr. Knowl. JMK 2020, 5, 163-172.

22. Kelliher, C.; Anderson, D. Doing more with less? Flexible working practices and the intensification of work. Hum. Relat. 2010, 63, 83-106. [CrossRef]

23. Hynes, M. Telework isn't working: A policy review. Econ. Soc. Rev. 2014, 45, 579-602.

24. Vilhelmson, B.; Thulin, E. Who and where are the flexible workers? Exploring the current diffusion of telework in Sweden. New Technol. Work Employ. 2016, 31, 77-96. [CrossRef]

25. Tremblay, D.G.; Thomsin, L. Telework and mobile working: Analysis of its benefits and drawbacks. Int. J. Work Innov. 2012, 1, 100-113. [CrossRef]

26. Ko, E.; Kim, A.; Kim, S. Toward the understanding of the appropriation of ICT-based Smart-work and its impact on performance in organizations. Technol. Forecast Soc. Change 2021, 171, 120994. [CrossRef]

27. Campbell, J.; McDonald, C. Defining a Conceptual Framework for Telework and an Agenda for Research in Accounting and Finance. Int. J. Bus. Inf. Syst. 2009, 4, 387-402. [CrossRef]

28. Baruch, Y. Teleworking: Benefits and pitfalls as perceived by professionals managers. New Technol. Work Employ. 2000, 15, 34-49. [CrossRef]

29. Marino, L.; Capone, V. Smart working and well-being before and during the COVID-19 pandemic: A scoping review. Eur. J. Investig. Health Psychol. Educ. 2021, 11, 1516-1536. [CrossRef] 
30. Sung, W.J. A study on the activation plan of smart work in public sector. J. Inf. Soc. Policy 2013, 20, 43-62.

31. Bucea-Manea-Tonis, R.; Prokop, V.; Ilic, D.; Gurgu, E.; Bucea-Manea-Tonis, R.; Braicu, C.; Moanta, A. The relationship between Eco-innovation and smart working as support for sustainable management. Sustainability 2021, 13, 1437. [CrossRef]

32. Sarker, S.; Xiao, X.; Sarker, S.; Ahuja, M.K. Managing employees' use of mobile technologies to minimize work-life balance impacts. MIS Q. Exec. 2012, 11, 1-5.

33. Golden, T.D. Applying technology to work: Toward a better understanding of telework. Organ. Manag. J. 2009, 6, 241-250. [CrossRef]

34. Leonardi, P.M.; Treem, J.W.; Jackson, M.H. The connectivity paradox: Using technology to both decrease and increase perceptions of distance in distributed work arrangements. J. Appl. Commun. Res. 2010, 38, 85-105. [CrossRef]

35. Kim, H.K. Agreement between the Q-block and Q-tool. J. Korean Soc. Sci. Study Subj. 2008, 16, 5-16.

36. McKeown, B.; Thomas, D. Q Methodology; Sage: Newbury Park, CA, USA, 1988.

37. Brown, S. Q methodology and qualitative research. Qual. Health Res. 1988, 6, 561-567. [CrossRef]

38. Gold, M.; Mustafa, M. Work always wins: Client colonisation, time management and the anxieties of connected freelancers. New Technol. Work Employ. 2013, 28, 197-211. [CrossRef]

39. Aggerholm, H.K.; Andersen, S.E.; Thomsen, C. Conceptualizing employer branding in sustainable organisations. Corp. Commun. Int. J. 2011, 16, 105-123. [CrossRef]

40. Choi, H.J.; Kim, Y.T. Work-family conflict, work-family facilitation and job outcomes in the Korean hotel industry. Int. J. Contemp. Hosp. Manag. 2012, 24, 1011-1028. [CrossRef]

41. Baum, T.; Mooney, S.K.; Robinson, R.N.; Solnet, D. COVID-19's impact on the hospitality workforce-new crisis or amplification of the norm? Int. J. Contemp. Hosp. Manag. 2020, 32, 2813-2829. [CrossRef]

42. Hao, F.; Xiao, Q.; Chon, K. COVID-19 and China's hotel industry: Impacts, a disaster management framework, and post-pandemic agenda. Int. J. Hosp. Manag. 2020, 90, 102636. [CrossRef] 